\title{
Migracije v slovenskem »zamejstvu « v Italiji po drugi svetovni vojni
}

\author{
Aleksej Kalc \\ ZRC SAZU, Inštitut za slovensko izseljenstvo in migracije \\ akalc@zrc-sazu.si \\ UP FHŠ, Oddelek za zgodovino in Inštitut za medkulturne študije \\ aleksej.kalc@fhs.upr.si
}

\section{Uvod}

Po drugi svetovni vojni se je Republika Slovenija v okviru Jugoslavije konstituirala v novih teritorialnih mejah. S priključitvijo Primorske in Istre je bila rapalska meja, ki je leta 1920 zahodni del slovenskega narodnega ozemlja in Istro s 450.000 prebivalci slovenske in hrvaške narodnosti dodelila Kraljevini Italiji, pomaknjena proti zahodu. Nova mejna črta je še vedno sekala slovensko narodno ozemlje in puščala v Italiji, v Avstriji in na Madžarskem številne slovenske kraje in slovensko prebivalstvo. To ni pomenilo le pripadnosti različnim državam, ampak tudi različnim geopolitičnim influenčnim sferam ter družbenopolitičnim sistemom. Slovenska zahodna in severna meja sta namreč sovpadali z globoko delitvijo med socialističnim in kapitalističnim svetom, meja z Madžarsko pa je od informbirojevskega razkola leta 1948 pomenila ideološko in sistemsko ločnico med jugoslovansko in sovjetsko inačico socializma, enako »trdo« in razdvajajočo kot meja z Zahodom.

Vojna in geopolitične spremembe ter družbenopolitične razmere po njej so ustvarile pogoje za nova migracijska gibanja, ki so jim botrovali politični, narodni in ideološki, nič manj pa tudi družbeni in gospodarski dejavniki. Severni in zahodni obmejni prostor ter »zamejstva« so se neposredno soočali z migracijskimi procesi kot prizorišča izseljevanj, priseljevanj in tranzitnih selitvenih gibanj. $\mathrm{V}$ tem je izstopalo zahodno obmejno območje. Priključitev Istre $\mathrm{k}$ Jugoslaviji in zapleteno reševanje »tržaškega vpraša- 
nja« sta tu povzročila množične in raznolike transferje prebivalstva ter korenite spremembe etnične strukture na eni in drugi strani državne meje. V migracijskih gibanjih so bili soudeleženi vse prisotne narodne skupnosti in pripadniki različnih ideoloških taborov ter političnih skupin. Izseljevanja in priseljevanja so bila neposredni učinki teritorialnih sprememb kot tudi posledice državnih politik, političnega ozračja in družbenoekonomskih situacij, ki so jim botrovali tudi sami migracijski premiki. Potekala so večinoma $\mathrm{z}$ vzhoda na zahod, a tudi v obratni smeri, iz kapitalističnega sveta $\mathrm{v}$ socialistično Jugoslavijo in iz slovenskih zamejskih območij v zahodni svet.

Prispevek ponuja sliko migracijskih gibanj, ki so od konca druge svetovne vojne do devetdesetih let 20. stoletja vidneje zaznamovala t. i. slovenski manjšinski ali »zamejski« prostor v Italiji. Predstavljeni so premiki prebivalstva, zgodovinski konteksti in specifične okoliščine, v katerih so se pojavili, ter njihova vloga v sooblikovanju družbene, politične in kulturne fiziognomije obravnavanega območja. Govorimo tudi o organizacijskih in identitetnih značilnostih migracijskih skupnosti, njihovih razmerjih z izvornimi okolji in njihovem mestu v zgodovinskih obravnavah ter zgodovinskih spominih.

\section{Med vojno in v letih po njej: povratniki, optanti, prebežniki in begunci}

Migracijska gibanja, povezana s spremembami politične geografije in upravnih režimov, so se v Julijski krajini začela že med vojno. Po razpadu Italije septembra 1943 in nemški zasedbi območja, ki je bilo vključeno v nemški rajh v okviru t. i. operacijske cone Jadransko primorje (Operationszone Adriatisches Kustenland), se je umaknila večina italijanskega prebivalstva, ki se je bila sem priselila po letu 1918. Ti priseljenci so po prvi vojni v nove italijanske vzhodne province prišli večinoma, da bi zasedli delovna mesta $v$ javni upravi in političnih organizacijah. Nadomeščali so slovenske in hrvaške ter druge uradnike in javne uslužbence bivše avstro-ogrske države (Troha 2000, 256-57). Italijanske priseljence pa so pritegnile tudi priložnosti gospodarskega udejstvovanja (Bearzatto 2012).

Hkrati so na Tržaško prihajali številni italijanski begunci iz Zadra in drugih območij Dalmacije, ki so se umikali pred vojnimi operacijami in zavezniškimi bombardiranji. Trst je takrat postal stalno ali samo začasno pribežališče beguncev na poti na Apeninski polotok. Od skupno 8.ooo dalmatinskih pribežnikov jih je skoraj polovica ostala v Trstu. Tu so se zbirali tudi mnogi s fašizmom kompromitirani politični ubežniki, ki so se iz slo- 
venskega in širšega jugoslovanskega prostora umikali pred prodirajočim partizanskim osvobodilnim gibanjem (Volk 2000, 270; 2003, 144). Dotok beguncev in drugega prebivalstva, ki se je premikalo proti zahodu zaradi političnih in vojnih dogodkov, se je na Tržaškem in Goriškem ob koncu vojne in v letih po njej le še znatno povečal.

Zadnje dni vojne in takoj po njej so se na ozemlju Julijske krajine pod upravo ZVU (Zavezniška vojaška uprava) zbirali oziroma naselili tudi politični begunci iz osrednje Slovenije in Jugoslavije. V dogovoru z ZVU so poleti 1945 začeli prihajati še iz taborišč v Italiji, kamor se jih je zateklo okrog 10.00o. Ti prihodi so bili večinoma povezani $\mathrm{z}$ zaposlovanjem $\mathrm{v}$ službah pri ZVU, ker so primorski Slovenci, po navodilih jugoslovanskih oblasti, ta službena mesta zavračali. Po mirovni pogodbi 1947 so službe v coni A STO (Svobodno tržaško ozemlje) nastopali tudi mnogi slovenski politični emigranti, ki so se sprva naselili na Goriškem. Večina se je potem izselila v Argentino in druge zahodne države (Troha 200o, 256, 264-65). Nekateri so na Tržaškem nadaljevali medvojno politično aktivnost in se angažirali v protirevolucionarnih organizacijah ter $\mathrm{v}$ obveščevalnih dejavnostih zoper jugoslovansko stran in jugoslovanske oblasti (Bajc 2010).

Od postavitve demarkacijske črte leta 1945 dalje je iz jugoslovanske strani na ozemlje Julijske krajine pod angloameriško in nato italijansko upravo legalno ter ilegalno prihajala pisana množica pribežnikov in priseljencev. Tako z Goriškega kot iz Istre so prihajali ljudje, ki so nasprotovali jugoslovanskim oblastem in novemu družbenopolitičnemu redu. Umikali so se pred uvajanjem novega družbenega reda in raznovrstnimi oblikami pritiska in nasilja, ki so ga jugoslovanske oblasti izvajale proti ljudem, kompromitiranim s fašističnim režimom, in vsem, ki niso bili naklonjeni novi ureditvi. Iz Istre so prihajali predvsem Italijani, a v znatnem številu tudi Slovenci in Hrvati, saj se novi socialistični red načeloma ni uveljavljal na podlagi narodne, pač pa družbene oziroma politično-ideološke diskriminante. Odhajanju so vsekakor pripomogli tudi napetosti in včasih pravo sovraštvo med narodnimi komponentami, ki so izhajali iz pred- in medvojnega obdobja kot tudi iz novonastalih razmer, ter dejstvo, da je bila večina italijanskega prebivalstva protijugoslovansko nastrojenega (Troha 200o, 259). Primorski prostor pod jugoslovansko oblastjo so zapuščali tudi Slovenci, ki so bili sicer naklonjeni NOB in Jugoslaviji, niso pa sprejemali komunističnega družbenopolitičnega reda. Tudi ti so bili na indeksu izključevalne politike proti nelojalnim osebam. Ker se niso vključevali v so- 
cialistične družbene organizacije, so postali tudi tarče šikaniranja s strani prebivalstva.

Odhodov niso spodbudili samo političnoideološki vzroki in motivacije. Demarkacijska črta in nato meja sta prerezali gospodarske in družbene vezi jugoslovanskega dela Primorske in Istre s Trstom, z Gorico, s Tržičem ter $\mathrm{z}$ drugimi tradicionalnimi zahodnimi gravitacijskimi centri. Številni so se zato pred in takoj po podpisu mirovne pogodbe ter razmejitvi leta 1947 odločali za prehod na italijansko stran Goriške oziroma v Cono A STO iz gospodarskih razlogov, zaradi službe, $v$ upanju na boljše življenjske pogoje kot tudi zaradi navezanosti ter na podlagi družinskih in sorodstvenih vezi (Troha 2000, 263-64). Te prihode je olajšalo in spodbujalo tudi dejstvo, da ZVU ni zavirala prostega premikanja med Cono A in B Julijske krajine in nato STO. Prehod demarkacijske črte je bil dovoljen $\mathrm{z}$ osebno izkaznico ZVU ali VUJA. Na ozemlju pod angloameriško vojaško upravo so prebivalcem $\mathrm{s}$ stalnim bivališčem $\mathrm{v}$ coni $\mathrm{B}$ priznavali enake pravice do zaposlovanja in stanovanja kot tistim s stalnim bivališčem v coni A, dovolj je bilo, da so bili stalno nastanjeni. (Volk 2003, 144-45)

Med priseljenci so bili t. i. optanti, ki so na podlagi mirovne pogodbe lahko ohranili italijansko državljanstvo. To pravico so imeli prebivalci italijanskega jezika, ki so 10. junija 1940 imeli domicil na območjih, ki so z mirovno pogodbo leta 1947 prešla pod Slovenijo oziroma Jugoslavijo. Prav tako so lahko za italijansko državljanstvo zaprosili družinski člani italijanskih optantov. Jugoslovanske oblasti so to pravico priznavale, ne glede na narodnost, tudi osebam, zaposlenim na območju, ki je ostalo Italiji, in političnim nasprotnikom novega družbenopolitičnega sistema. Od 22.400 vlog za opcijo so jih zavrnile samo nekaj več kot 1.000 (Troha 2000, 256). Med Slovenci je bilo tudi veliko prebežnikov, ki so se odločali za zelo tvegamo in pogosto življenjsko nevarno ilegalno prekoračitev meje. To so varovale posebne enote Sekretariata za notranje zadeve, ki so vzdolž več kilometrov širokega jugoslovanskega obmejnega pasu izvajale zelo strog nadzor za preprečevanje prebegov (Vidmar 2015). Številčni obseg ilegalnih prehodov ni dokončno ugotovljen. Viri navajajo, da je iz okraja Gorica leta 1947 pobegnilo 1.814 oseb, do leta 1951 pa še 88o. Italijanske oblasti so tudi tem pribežnikom, ki niso izpolnjevali pogojev za opcijo italijanskega državljanstva, priznali enak status kot ostalim beguncem iz Jugoslavije (Troha 2000, 264; 2010; Vidmar 2015).

V povojnem času so se na ozemlje Primorske, ki je z razmejitvijo ostalo Italiji oziroma do 1954 tvorilo cono A STO, vračali Slovenci iz ujetništva, 
internacije in konfinacije. Nazaj so prihajali tudi tisti, ki so bili pod fašizmom načrtno službeno premeščeni po Italiji ali so se tja izselili iz drugih razlogov. Samo bivših državnih uslužbencev je bilo med temi slovenskimi in hrvaškimi povratniki več kot 5.550. Tisti, ki so imeli 10. junija 1940 domicil na ozemlju, ki je leta 1947 pripadlo Jugoslaviji, so lahko na podlagi mirovne pogodbe optirali za jugoslovansko državljanstvo. Od političnih in gospodarskih emigrantov iz fašističnega obdobja $\mathrm{v}$ druge evropske in prekomorske države so se vrnili le posamezniki (Troha 2000, 155-266). Več takih emigrantov je v cono A STO prišlo iz Jugoslavije, ki je bila med vojnama najpogostejši cilj slovenskih in hrvaških političnih ter gospodarskih izseljencev iz Julijske krajine $\mathrm{v}$ času fašizma. Potekal pa je tudi obratni tok: iz cone A Julijske krajine in nato STO so v cono B Julijske krajine, STO in $\mathrm{v}$ Jugoslavijo odhajali pripadniki NOB, politični aktivisti in sodelavci jugoslovanskih oblasti (Troha 2000, 259). Umikali so se preganjanju ZVU, nekateri so se za to odločali iz gospodarskih razlogov, nastopali so službe $\mathrm{v}$ novem upravnem aparatu cone B STO in po Jugoslaviji.

Za odhod v Jugoslavijo se je po končani vojni odločilo tudi 3.500 italijanskih in nekaj slovenskih delavcev z Goriškega in s Tržaškega. Bili so večinoma komunistično orientirani, podpirali so Jugoslavijo in bili vključe$\mathrm{ni} \mathrm{v}$ projugoslovanske sindikalne organizacije. Emigrirali so na Reko in v druge kraje $\mathrm{v}$ želji, da uresničijo delavske ideale in sodelujejo pri gradnji socializma. Njihovo selitev so jugoslovanske oblasti in sindikati uravnavali glede na potek razmejitvenih pogajanj in spremembe politične strukture $\mathrm{v}$ Tržiču (na Goriškem), do katerih je prihajalo z naselitvijo protijugoslovansko in protidelavsko nastrojenih beguncev iz Istre. Jugoslavija je to priseljevanje izkoristila tudi kot politični argument proti napadom italijanske propagande v zvezi s t. i. »eksodusom « iz Istre. Ob sporu z Informbirojem so se ti delavci v glavnem opredelili za Sovjetsko zvezo in večina se je, včasih po aretacijah in konfinacijah, vrnila na Goriško in v Trst. Zaradi brezposelnosti so nato dela iskali v Franciji, Švici in na Švedskem. Izseljevanje delavstva s tega območja $\mathrm{v}$ Jugoslavijo se je nadaljevalo, vendar iz gospodarskih razlogov (Troha 1999, 225-32; 2000, 256, 262-63; Purini 2010, 259-68).

\section{Priseljevanje begunskega prebivalstva iz Istre in njegove posledice}

Najizrazitejše migracijsko dogajanje, povezano s povojno razmejitvijo in teritorialno ureditvijo, je bilo v goriškem in tržaškem zamejskem prostoru priseljevanje begunskega prebivalstva iz Istre. Šlo je za pravi »protiudarec» 
pojava, ki ga je italijanska stran $\mathrm{v}$ propagandne namene poimenovala »istrski eksodus" (esodo istriano). Čeprav je predstavljal le majhen del transferjev prebivalstva, ki so spremljali narodno in ideološko prestrukturiranje povojne evropske politične geografije, je $\mathrm{v}$ prostoru bivše Julijske krajine na obeh straneh nove meje privedel do občutnih sprememb $v$ družbeni in etnični strukturi ter v kulturnem in političnem značaju območja. Begunci oziroma optanti in njihova politična raba s strani proitalijanskega bloka ter njegovih organizacij so ključno prispevali k uveljavljanju stališča o priključitvi Trsta in cone A STO Italiji.

Kot že omenjeno, je prihajanju istrskega prebivalstva na Tržaško in Goriško mogoče slediti od kapitulacije Italije dalje. Na Goriškem se je načrtno naseljevanje italijanskih istrskih beguncev začelo že po priključitvi ozemlja Italiji leta 1947. V coni A STO je do leta 1950 ZVU stalno naseljevanje zaradi bojazni pred socialnimi in političnimi posledicami oteževala. Italijanska vlada in proitalijanski politični tabor v coni A pa sta si begunce, ki bi morali po določilih mirovne pogodbe iti v Italijo, prizadevala zadržati $\mathrm{v}$ Trstu in $\mathrm{v}$ tem prikrito ter mimo zakonskih ovir $\mathrm{v}$ določeni meri tudi uspela. ZVU, ki se je $\mathrm{v}$ prvih letih po razmejitvi bala, da bi prisotnost beguncev poslabšala že tako hude socialne in gospodarske razmere ter premaknila tržaško javnost na levo, je s časom začela popuščati, ker so begunci krepili italijanski protikomunistični tabor in s tem koristili interesom ZVU. Leta 1947 in 1948 je bilo namreč v coni A STO 25.00o in več brezposelnih, na začetku petdesetih let je njihovo število upadlo na okrog 20.000 (Panjek 2011, 72).

Odhajanje v Italijo je potekalo organizirano in begunci so bili deležni pomoči s strani pristojnih italijanskih odborov za upravljanje pojava že od trenutka, ko so izrazili namen, da zapustijo svoje istrske domove. Podobne pomoči so bili deležni tudi begunci slovenske in hrvaške narodnosti, a samo potem, ko so že dospeli v Cono A STO, zato da bi ne spodbujali njihovega dotoka, ki bi na Tržaškem krepil slovensko komponento prebivalstva. Vpliv beguncev je na političnem polju prišel do izraza ob volitvah 1949, ko je zahvaljujoč italijanski strani naklonjenim volilnim pravilom, nelegalnemu priznavanju volilne pravice beguncem in razkolu komunističnega tabora zaradi Informbiroja okrog 30.000 begunskih volivcev občutno prispevalo k okrepitvi italijanskega tabora, predvsem stranke Krščanske demokracije (Troha 2000, 261; Volk 2003, 151-60; Panjek 2011, 88-98). Priseljevanje se je močno pospešilo ob tržaški krizi leta 1953 in Londonskem memorandumu, sprejetemu 1954, ko je bila določena razdelitev ozemlja STO med Italijo 
in Jugoslavijo. Takrat je »eksodus«, do katerega je drugod v Istri prišlo po letu 1947, množično zajel še del STO, ki je bil dodeljen Jugoslaviji, in prešel v svojo zaključno fazo. Od konca vojne do leta 1958 se je s tega območja odselilo 28.0oo oseb, od tega dve tretjini po oktobru 1953. Večina je bila optantov, ki so izbrali italijansko državljanstvo na podlagi Spomenice o soglasju, številni pa so odšli tudi ilegalno. Približno 30 \% je bilo Slovencev in Hrvatov. Številni slovenski optanti so bili iz dela Cone A v Miljskih hribih, ki je pripadla Jugoslaviji in je gospodarsko gravitirala proti Miljam in Trstu (Troha 2000, 260-61; Lavrenčič 2012; Kalc 2019; Gombač 2005).

ZVU je že leta 1950 spremenila svojo politiko do istrskih beguncev in v večji meri dopuščala njihovo načrtno naseljevanje na Tržaškem, ki ga je izvajal proitalijanski tabor. $\mathrm{K}$ temu so prispevale volitve $\mathrm{v}$ coni A leta 1949 in v coni B leta 1950, ki so dobile značaj plebiscita za Italijo oziroma Jugoslavijo. Prve so privedle do okrepitve vezi cone A STO z Italijo, volitve ljudskih odborov v coni B leta 1950 pa so pospešile uvajanje socialističnega reda v tem delu STO. Naseljevanje beguncev na Tržaškem se je povečalo, ko je bilo po dogovoru med ZDA, Veliko Britanijo in Italijo leta 1952 imenovanje vodstvenega kadra civilnega aparata uprave cone A STO prepuščeno italijanski vladi in njenemu političnemu vplivu, predvsem pa po priključitvi ozemlja cone A k Italiji (Purini 2010, 275-86; Panjek 2011, 116-17).

Italijanska lokalna in državna oblast sta takrat v obmestnem predelu in slovenski okolici zgradili vrsto naselij za istrske begunce in s tem izpeljali načrt narodne melioracije tržaškega območja. To je pomenilo namestitev italijanskega prebivalstva na slovenska območja za korekcijo etnične karte in utrditev italijanstva ob vzhodni italijanski meji. Specifični cilj je bil vzpostaviti kontinuiteto italijanske poselitve obmorskega pasu, ki so jo prekinjale slovenske vasi med Devinom in Barkovljami. Begunska stanovanjska naselja pa so nastala tudi v mestnih in predmestnih območjih $\mathrm{z}$ visoko koncentracijo levičarsko usmerjenega delavstva (Volk 2003, 183-84, 203-4, 225-26, 262-72; Purini 2010, 311-22). Zasilna in stalna stanovanja za begunce oziroma optante iz Istre so s finančno podporo Italije na Tržaškem gradili že od leta 1950.

Gradnje za begunce so se povečale po letu 1954 in trajale do leta 1967, ko se je proces narodne melioracije idejno zaključil. Na Tržaškem se je v okviru tega političnega načrta stalno naselilo skoraj 70.00o istrskih in dalmatinskih beguncev. V ta namen je bilo v slovenskih okoliških vaseh razlaščenih preko 100 hektarov zasebnih zemljišč, uporabljenih pa je bilo tudi 50 hektarov »jusarskega« (skupnega vaškega) kmečkega sveta (Volk 2003, 
260, 278). Odnosi med domačini in begunci so posebno in zanimivo poglavje, ki pa ga tu ne moremo obravnavati. Povejmo le, da je bilo med lokalnim vaškim in tudi mestnim prebivalstvom na Tržaškem zaznati nezadovoljstvo in nestrpnost do istrskih beguncev, in sicer zaradi njihovega izrabljanja v politične namene, ki je (poleg mednarodnih) okužilo tudi lokalne družbene odnose, in zaradi tega, ker se je tržaško prebivalstvo čutilo zapostavljeno. Posebno občutljivi so bili, poleg Slovencev, levo in indipendentistično usmerjeni krogi, katerih odnose $\mathrm{z}$ italijanskimi oblastmi je zaznamovalo obojestransko nezaupanje. Množična naselitev begunskega prebivalstva se je ob utrjevanju etnične meje uporabljala tudi za spodnašanje delavskih političnih sil na Tržaškem. Istrske organizacije in politiki iz begunskih vrst so imeli močan vpliv na nadaljnje volilne izide ter politično usmeritev tega prostora.

\section{Slovenska politična emigracija}

Omenjeno je bilo, da je današnje slovensko zamejstvo v Italiji po drugi svetovni vojni postalo pribežališče slovenskih političnih emigrantov in da so ti $\mathrm{v}$ zamejski stvarnosti zapustili pomemben pečat. Osnovna značilnost te emigracije je, da so jo skoraj brez izjeme sestavljali izobraženci in med njimi prodorni kulturni in politični delavci. Za večino sta bili Goriška in predvsem Tržaška le vmesni postanek na begu pred zmagovalci in komunistično oblastjo. Tu so se namreč ustalili samo nekateri, večina se je po krajšem ali nekajletnem obdobju podala naprej v druge države. Na te odločitve so vplivali razni dejavniki. Najprej dejstvo, da so že predhodno imeli v načrtu druge cilje in so jih tik za mejo ter še prej demarkacijsko črto zadržale politične razmere in organizacijske ter birokratske težave, $s$ katerimi so se soočali kot »razseljene osebe (displaced persons). Drugič, prihodnost Trsta je bila sprva negotova, saj je bila predmet mednarodnega političnega in diplomatskega dogajanja in ni bilo jasno, komu bo mesto pripadlo.

Cona A Julijske krajine in predvsem STO sta bili pomembno območje delovanja obveščevalnih služb komunističnih oziroma zahodnih ter protikomunističnih držav, obenem pa prizorišče ostrih političnih bojev v okviru te kontrapozicije na lokalni in širši ravni. Slovenski politični emigranti so bili tarča ne samo političnih pritiskov projugoslovanskih političnih organizacij in samega lokalnega slovenskega prebivalstva, ki je bilo $\mathrm{v}$ večini naklonjeno NOB in socialistični Jugoslaviji. Prišlo je tudi do ugrabitev in ubojev s strani jugoslovanskih varnostnih služb. Naklonjenosti niso uživali niti pri italijanskih oblasteh, ker so ne glede na svetovni nazor številčno in 
predvsem intelektualno krepili slovensko komponento prebivalstva. Živeli so v stalni začasnosti, ki se je za tiste, ki so ostali, nadaljevala tudi po tem, ko je območje prešlo pod Italijo. Ta jim dolgo ni priznavala pravice do državljanstva, zaradi česar so bili mnogi prikrajšani za stalne službe oziroma stalež v javnih ustanovah (Volk 1998, 88; Troha 1999, 242-44).

Prihod slovenskih političnih emigrantov na Tržaško je sovpadal z umikom jugoslovanske vojske sredi leta 1945 in s prevzemom ozemlja s strani ZVU. Območje so v večjem številu začeli zapuščati po mirovni konferenci 1947 in nato po priključitvi cone A STO Italiji. Z ukinitvijo STO je propadel tudi načrt, da bi emigracija s svojo politično dejavnostjo na Tržaškem ustvarila postojanko alternativne politične opcije nasproti socialističnemu redu, nekakšen politični laboratorij za zamenjavo družbenopolitičnega reda v Sloveniji. Temu so namreč sprva napovedovali kratko življenje in verjeli v skorajšnji povratek $\mathrm{v}$ domovino, odrešeno komunističnega sistema. Za časa upravnega dvovladja, ko sta si v coni A Julijske krajine oblast in vpliv delili ZVU in PNOO, je bila slovenska emigracija pomemben politični partner na strani antikomunističnega tabora in za boj proti organizacijam, ki so se prepoznavale v OF. Bila je tudi vodilna skupina med Slovenci na Primorskem, ki so, v nasprotju z večinsko, »OF-arsko« stranjo, zagovarjali sodelovanje z ZVU za zagotavljanje slovenskih narodnih pravic. Z odhodom večine emigrantov se je njena politična vloga le delno zmanjšala, saj je pod njenim vplivom katoliška politična struja zasedla zelo viden položaj v antikomunističnem taboru slovenske zamejske skupnosti in vplivala tudi na njen liberalni del, ki je nadaljeval predvojno tradicijo liberalno-katoliške Edinosti. Ta vpliv so izvajali preko politične, prosvetne, socialne in verske organiziranosti. Ustvarili so slovensko katoliško kulturno gibanje s sistemom organizacij na najrazličnejših področjih, od publicistike in dramskega udejstvovanja do kulturnih in študijskih pobud, kakršne so bili tabori in diskusijski forum Draga. Sodelovali so pri ustanovitvi in vodenju demokratičnih oziroma antikomunsitičnih političnih organizacij. S svojimi integralističnimi in nepopustljivimi katoliškimi stališči so v zamejski politični prostor vnašali medvojni politični spor iz osrednje Slovenije in s tem razkol v protikomunističnem taboru. To se je pokazalo pred ukinitvijo STO, ko se je del tabora odločil za zbližanje z Jugoslavijo, ki je lahko zamejskim Slovencem odtlej edina nudila oporo pri uveljavljanju narodnih pravic (Volk 1998, 94-97).

Pomembno področje udejstvovanja politične emigracije je bilo šolstvo; ZVU ji je namreč zaupala reorganizacijo slovenskega zamejskega šol- 
stva. Poleg obnove oziroma vzpostavitve srednjih šol je to pomenilo zmanjšanje in odpravljanje vpliva, ki ga je imel na šolstvo PNOO. Predstavniki politične emigracije so bili pristojni za zaposlovalno in habilitacijsko kadrovsko politiko, pripravo učbenikov namesto tistih, uvoženih iz Slovenije, in sestavo učnih načrtov. Pri tem so si prizadevali za odpravljanje vplivov komunizma ter odstranjevanje nezanesljivega ali nasprotno mislečega učnega kadra. Ker je ta politika naletela na proteste javnega mnenja, PNOO, italijanskega šolskega vodstva in samih svetovnonazorsko bližjih slovenskih šolnikov (ti so zahtevali prednost zaposlovanja domačega kadra pred tistim iz emigrantskih vrst), je ZVU odstranila politično najbolj ekstremistične elemente iz desnega in levega tabora. Po drugi strani je pri uveljavljanju slovenskega šolstva prihajalo do sodelovanja med nasprotujočima si ideološkima taboroma, ki sta imela na tem področju skupnega nasprotnika v italijanskem nacionalizmu (Volk 1998, 91-92).

Politični emigranti so bili pomemben politični dejavnik tudi na področju medijev. V letih 1945-47 jih je ZVU zaposlila v uredništvu Glasa zaveznikov, nato pa na radiu, ki je bil ravno tako podrejen politični liniji zaveznikov in je bil glasnik protikomunistične propagande. Radio, ki so ga ustanovile partizanske oblasti za časa svoje uprave, je do leta 1946 imel tudi uslužbence iz vrst SIAU, do leta 1949 pa je v kulturnem programu sodeloval tudi z Radiom Slovenija. Nato se je zaradi vse ostrejših stališč sodelovanje prekinilo, leta 1955 pa je radio prešel pod italijansko nacionalno radiotelevizijo. Od petdesetih letih mu je vsebinsko in politično usmeritev dajala politična emigracija. $Z$ odhodom dela beguncev se je začelo obnavljati sodelovanje $\mathrm{z}$ radijsko hišo $\mathrm{v}$ Sloveniji. Kader iz vrst politične emigracije, ki se je za stalno naselil na Tržaškem, pa je ohranil pomembno vlogo in ključno prispeval k razvoju radia kot ene izmed vodilnih zamejskih informativnih in kulturnih ustanov. Politični emigranti so dali svoj prispevek tudi zamejskemu antikomunističnemu tisku. Objavljali so v Katoliškem glasu in Demokraciji, kjer so zastopali linijo predvojnega katoliškega tabora v Sloveniji. Zelo aktivno so sodelovali tudi pri časopisju in publicističnih pobudah slovenske politične emigracije po svetu (Volk 1998, 93).

\section{4. "Avstralski val« in druga izseljevanja v tujino}

Današnji slovenski zamejski prostor $\mathrm{v}$ Italiji je bil $\mathrm{v}$ nemirnem in negotovem času nastajanja povojne razmejitve priča tudi procesom izseljevanja avtohtonega prebivalstva $v$ tujino. Tudi temu izseljevanju so botrovali politični in družbenoekonomski dejavniki in ga je treba razbirati v kontekstu 
takratnih regionalnih ter lokalnih okoliščin in mednarodnih političnih ter ideoloških dogajanj. Takoj po končani vojni so zaradi gospodarske situacije in političnih napetosti mnogi, naslanjajoč se na sorodstvene in druge zveze, sledili predvojnim izseljencem $\mathrm{v}$ tujino. Nekateri so se odzvali na priseljenske programe raznih prekomorskih držav in se odločili za Kanado in ZDA, nato za Venezuelo in Brazilijo, številčno je bilo, kot že omenjeno, $v$ nekaterih letih tudi izseljevanje $\mathrm{v}$ Jugoslavijo, a vseskozi tisto v Italijo (Purini 2010, 302; Panjek 2011, 56-58, 98).

Omembe vreden je odhod tržaških Judov, ki so se po vrnitvi iz v raznih koncev sveta, $v$ katere so se zatekli pred in med vojno, od mesta zaradi popolnoma izginule judovske skupnosti spet poslovili in večinoma odšli v Palestino (Purini 2010, 301). Zelo specifičen in po strukturi izstopajoč je bil za časa ZVU pojav, ki so ga poimenovali izseljevanje "ameriških" in "angleških nevest «. Šlo je za dekleta, med njimi tudi slovenska, ki so se poročila $\mathrm{z}$ angleškimi in ameriškimi uslužbenci vojaške uprave cone A Julijske krajine in STO z njimi odšla v ZDA oziroma Veliko Britanijo. Statistike govorijo $\mathrm{o} 482$ in 353 porokah $\mathrm{z}$ ameriškim oziroma angleškim vojaškim osebjem ter o 1.300 nevestah, odseljenih v ZDA. Med temi niso bile samo ženske iz cone A Julijske krajine in STO, ampak tudi iz cone B in v desetih odstotkih primerov žene ameriških vojakov, ki so jih službeno premestili na Tržaško iz Italije (Purini 2010, 301-2).

Najopaznejše, tako $\mathrm{z}$ demografskega kot družbenega, političnega in emotivnega vidika, pa je bilo množično izseljevanje v Avstralijo, ki je zajelo Goriško, zlasti pa Trst in njegovo okolico tik pred in v prvih letih po ukinitvi STO in priključitvi njegove bivše cone A k Italiji. Ta pojav se umešča $\mathrm{v}$ širši okvir povojnega izseljevanja v prekomorske dežele, povezanega s t. i. »razseljenimi osebami« ter političnimi begunci, ki so iskali »nove domovine« in priložnost za življenje. Porušena Evropa jim ni mogla zagotoviti domovanja, zato so jih mednarodne organizacije usmerjale $\mathrm{v}$ čezoceanske dežele. Trst je zaradi bližine železni zavesi postal pomembno zbirno središče in center za upravljanje tega prometa. V mestu je pod okriljem Organizacije združenih narodov delovala Mednarodna organizacija za begunce IRO (International Refugee Organization) in od leta 1952 njen naslednik, Medvladni odbor za izseljevanje iz Evrope - ICEM (Intergovernmental Committee for European Migrations; Fait 1999, 27-29, 34-35; Panjek 2011, 89). Organizaciji sta skrbeli za odpravljanje beguncev v ZDA, Venezuelo in Brazilijo, ko se je receptivnost teh držav zmanjšala, pa v Kanado, Južno Afriko in predvsem v Avstralijo. To možnost so izkoristili tudi mnogi itali- 
janski begunci iz Istre in Dalmacije. Do leta 1951 se jih je iz cone A STO več kot 3.000 izselilo v ZDA, Venezuelo in Avstralijo. V naslednjih letih so jim sledili še drugi, od leta 1954 dalje pa sami Tržačani. Tudi ti so se večinoma podali v Avstralijo. Obstaja ocena, da se je v celotnem povojnem obdobju (1945-1965) iz Trsta skupaj izselilo 60.00o Tržačanov, približno tretjina do priključitve Italiji (1954), preostali pa zatem (Panjek 2011, 58-60).

Izseljevanje v Avstralijo je sodilo v program priseljevanja, ki ga je ta država izvajala po vojni, da bi zapolnila prebivalstveni deficit in zadostila potrebam po delovni sili za svojo ekonomijo ter predvsem za razvoj velikih javnih infrastruktur. Tržaški izseljenci so sodili v kvoto, ki jo je Avstralija namenila priseljencem iz Evrope, s tem, da je zanje rezervirala posebne priseljenske programe. Začetki tega izseljevanja iz Trsta segajo v zgodnja petdeseta leta. Pravi val izselitev pa se je zgodil v triletju od 1954 do 1956, to je ob višku politične krize, ki je privedla do odprave STO in izseljevanju istrskega prebivalstva iz njegove cone B (Fait 1999, 37-46).

Ocenjuje se, da je izseljevanje v Avstralijo, ki se je po malem nadaljevalo še do začetka šestdesetih let, zajelo med 15.000 in 20.000 Tržačanov in vsaj 533 prebivalcev Goriške (Purini 2010, 337-42). Slovenski avtorji so na podlagi šoloobveznih otrok, ki so na Tržaškem zmanjkali v slovenskih in italijanskih šolah zaradi izselitve, ocenili, da je bilo 30 odstotkov izseljencev Slovencev (Stranj 1982; 1991). Upoštevati je treba, da je ugotavljanje narodnosti na etnično mešanih območjih, kakršno je bilo Tržaško, problematično. To še posebej velja za takratne politične razmere in ideološke delitve, ki jih je povzročil kominform, zaradi katerih je prihajalo do prepisovanja otrok iz slovenskih v italijanske šole. Pojav je v slovenskem prebivalstvu vsekakor pustil sorazmerno večje demografske posledice kot $\mathrm{v}$ italijanskem.

Vzroki izseljevanja so bili družbenoekonomski in hkrati politični. Tržačani so se za odhod odločali po eni strani zaradi negotovih gospodarskih in družbenih razmer, ki so zavladale v Trstu po ukinitvi STO in odpravi ekonomije, ki jo je vzdrževala ZVU. Tržaškemu gospodarstvu so zmanjkala zavezniška naročila in nasploh povpraševanje ob tem, da je sama ZVU zaposlovala 13.000 Tržačanov. S prehodom pod Italijo se je mesto moralo soočiti z italijanskim ekonomskim trgom in visoko stopnjo brezposelnosti. Italijanska zakonodaja je pri zaposlovanju v javnem sektorju dajala prednost istrskim beguncem, kar je zaznamovalo tudi odnos Tržačanov do pribežnikov iz Istre. Zaostrila se je stanovanjska kriza. Nastopila je psihoza brezperspektivnosti, ne samo med brezposelnimi, ampak tudi med 
kvalificiranim delavstvom in sploh med ljudmi z zagotovljenim delovnim mestom, ki so se odzivali avstralskim priseljenskim programom v upanju v svetlejšo prihodnost. Številni pa so se za to odločili, ker so kot podporniki indipendentistične ideje o Svobodnem tržaškem ozemlju nezaupljivo doživljali vrnitev Italije. Čutili so se opeharjene in nemočne v politični igri, ki je imela za cilj etnično in svetovnonazorsko spremembo tržaškega družbenega tkiva ter privilegiranje Italiji všečnega begunskega prebivalstva. $\mathrm{V}$ ta namen je italijanska vlada bivšim uslužbencem ZVU priznavala bonitete, če so se odrekli pravici službenega mesta v italijanski javni upravi (glej Glej Kalc in Pahor 1993; Fait 1999, 47-54; Kalc 2004; Purini 2010, 344-350; Cresciani 2011, 45-47).

Pripadniki indipendentističnega tabora in levičarsko usmerjenega delavstva so se bali tudi morebitnega političnega preganjanja, saj pri italijanskih oblasteh niso uživali simpatij. Poseben primer so bili uslužbenci zavezniške policije, ki so jim italijanski nacionalisti očitali protiitalijansko in celo proslovensko nastrojenost. Odšli so s prvimi transporti, ožjo skupino pa je anglo-ameriška uprava zaščitila tako, da jo je pred predajo oblasti umaknila v Veliko Britanijo (Cresciani 2011, 34-35). Slovenci so zaradi fašistične izkušnje vrnitev Italije $v$ Trst sprejeli s še večjim nezaupanjem. Njihova odločitev za Avstralijo je bila v primerjavi z italijanskimi someščani še dodatno politično in ideološko obarvana. Odhod tolikih družin z otroki in mladih samskih ljudi je pomenil, ob asimilaciji, pomemben negativni dejavnik v nadaljnjem demografskem in družbenem razvoju slovenske narodne skupnosti (Purini 2010, 350-54). Zgovorne so statistike vpisov v slovenske šole, na katere pa je poleg izseljevanja vplivala asimilacija: od šolskega leta 1954/55 do 1957/58 je število vpisov v slovenskih osnovnih šolah na Tržaškem upadlo za petino (Purini 2010, 354).

Tržaško izseljevanje v Avstralijo se je uvrščalo v program mednarodno podprtih selitev (Assisted Passage Program). Te so potekale v okviru dogovorov med državami izseljevanja in priseljevanja in $\mathrm{v}$ režiji državnih organov ter namenskih mednarodnih organizacij. Avstralija je imela z ZVU in Italijo podpisan dvostranski dogovor za sprejemanje delovne sile na podlagi kolektivnih delovnih pogodb. S prehodom Trsta pod Italijo se je že obstoječa migracijska shema lahko nemoteno nadaljevala. Razpisane so bile kvote za izseljence iz Trsta, upravljanje izseljevanja pa je potekalo $\mathrm{v}$ skupni režiji tržaškega Urada za delo, avstralske vlade in ICEM (Fait 1999, 37-40). Tržaški urad ICEM je v letih od 1952 do 1962 večinoma v Avstralijo (in v manjšem številu $\mathrm{v}$ ZDA in druge države) odpravil skoraj 25.00o iz- 
seljencev. Od tega je bila polovica Tržačanov, polovica pa beguncev iz raznih vzhodnih držav, največ iz Jugoslavije in Sovjetske zveze (Panjek 2011, 151-54). Izseljenci so imeli v tem sistemu vrsto olajšav: brezplačni potni list, brezplačno ali kreditirano potovanje, sprejem $\mathrm{v}$ namenskih zbirnih centrih. Ker je država izvora državi sprejemnici morala jamčiti za kvaliteto delovne sile, so bili ti programi precej selektivni. Priseljenci so morali ustrezati točno določenim demografskim, zdravstvenim in poklicnim kriterijem. $\mathrm{V}$ ta namen je avstralska komisija $\mathrm{v}$ Trstu preverjala njihova poklicna znanja in delovne sposobnosti. Biti so morali tudi politično neoporečni, kar je pomenilo, da niso smeli biti nosilci ekstremističnih idej. Zato so na selekcijah mnoge zavrnili. Ti so potem odhajali v tujino samostojno po drugih poteh (Fait 1999).

V okviru izseljenskega programa je bilo poskrbljeno za izpeljavo birokratskih postopkov in organizacijo, od trenutka prijave za izselitev do namestitve in zaposlitve $\mathrm{v}$ Avstraliji. Prijaviti so se smeli samski moški in ženske, stari od 18 do 35 oziroma 30 let. Poročeni partnerji so lahko bili stari do 35 let, če je šlo za cele družine $z$ otroki, pa je družinski poglavar smel biti star do največ 45 let. Sprejemali so tudi poročene moške, ki so nameravali za sabo poklicati družino. Avstralija oziroma Commonwealth je priseljence sprejel za dobo dveh let in jim jamčil enake pravice, delovne pogoje in plačilni režim kot avstralskim delavcem. Pred odhodom pa se je izseljenec moral s pogodbo obvezati, da bo $\mathrm{v}$ Avstraliji dve leti na voljo vladi in da bo sprejemal delo, ki mu ga bo ta dodelila oziroma ponudila. Kršitelji tega pravila in predčasni povratniki so bili avstralski državi dolžni vrniti stroške za svojo priselitev. Priseljenci, ki so izpolnili pogoje, so lahko po dveh letih zaprosili za nadaljnje bivanje v Avstraliji, po petih pa za državljanstvo (Fait 1999, 40-46).

V Trstu so na selekcijah zavrnili dobro petino kandidatov. V primerjavi z italijanskim povprečjem je bil ta odstotek nizek. To je pripisati dejstvu, da so bili med prosilci številni uslužbenci ZVU, kar so jim šteli kot dokaz ustreznosti zahtevam Commonwealtha, in visokemu strokovnemu profilu kandidatov (Fait 1999, 41). V ozadju pa je bila tudi želja Italije, da čim več prosilcev za izselitev dejansko zapusti Trst (Tonel 1999, 50).

Značilnost tržaškega izseljevanja v Avstralijo je bila vsekakor poklicna struktura, saj so bili izseljenci večinoma mestni ljudje, zaposleni v industriji, javnem sektorju in vrsti drugih kvalificiranih poklicev. Poklicna kvalifikacija sicer ni avtomatično odpirala poti do ustrezajoče službe. Na začetku so priseljenci pogosto opravljali nekvalificirana dela. Prvič, ker so 
poklicne kvalifikacije morale potrditi avstralske sindikalne organizacije in organi za delo. Drugič, ker je avstralska država potrebovala delavce brez stalne zaposlitve, da jih je lahko razmeščala v skladu s sprotnimi potreba$\mathrm{mi} \mathrm{v}$ industriji, pri infrastrukturnih delih in $\mathrm{v}$ drugih strateških gospodarskih panogah. Zlasti velika javna dela v klimatsko neprijaznih, neobljudenih območjih so terjala stalno nadomeščanje delovne sile, ker življenja $\mathrm{v}$ tako ekstremnih razmerah ni bilo mogoče dlje vzdržati, ne glede na to, so se tržaški priseljenci v sektorjih srednje in višje kvalificiranega dela uveljavili prej kot priseljenci iz drugih držav. Sam tržaški in urbani izvor sta bila dobra popotnica, če že ne jamstvo za pridobitev boljših delovnih mest tako za kvalificirane kot za navadne delavce (Fait 1999, 77-81). Značilnosti in pomen tega izseljevanja s Tržaškega se kažejo tudi v njegovi demografski in družbeni strukturi. 44 odstotkov izseljencev je bilo ženskega spola, od tega 60 odstotkov žen in mater, saj so odhajale številne družine. Temu primerno je bilo tudi število otrok, ki so predstavljali četrtino vseh izseljencev. Med delavci je bilo 55 odstotkov kvalificiranih oziroma specializiranih, največ v metalurškem, gradbenem in lesarskem sektorju, med delavkami pa je bila večina srednje in nižje specializiranih (Fait 1999, 114, 120, 123).

Tržaški priseljenci so se naselili predvsem $v$ avstralske metropole, zlasti v Melbourne in Sydney (Nodari 1991). Kmalu so se organizacijsko povezali in reproducirali »tržaško " skupnost s specifičnimi identitetnimi in kulturnimi značilnostmi (Nelli 1988; 1999; Cresciani 1999; 2011, 121-63). Izkušnja in izbire slovenskih Tržačanov so se delno ujemale $\mathrm{z}$ organizacijskim in s kulturnim kontekstom tržaške skupnosti, delno so od tega odstopale, ubrale alternativno pot in se povezale s priseljenskimi skupnostmi iz Slovenije (Kalc in Pahor 1993; Kalc 2004). Podobno kot drugi izseljenski pojavi je tudi tržaško izseljevanje v Avstralijo poznalo povratništvo. Del izseljencev se je vrnil že po nekaj letih bivanja v Avstraliji, največ zaradi težav s prilagajanjem tamkajšnjemu življenju (Nodari 1986; Fait 1999, 87-90). V naslednjih letih pa sta $\mathrm{k}$ temu pripomogla normalizacija družbenih in gospodarskih razmer $v$ Trstu ter skokoviti ekonomski napredek, ki ga je Italija beležila $\mathrm{v}$ šestdesetih in sedemdesetih letih 20. stoletja.

\section{Beneška Slovenija in Rezija}

Najizrazitejše razsežnosti je izseljenski pojav $\mathrm{v}$ slovenskem zamejstvu $\mathrm{v}$ Italiji dosegel v videmski pokrajini, posebno v Reziji, Nadiških in Terskih dolinah. Rezija in Beneška Slovenija sta imeli kot celotna Furlanija dolgo migracijsko tradicijo. V hribovitih območjih so bile delovne migracije po- 
membna komponenta gospodarskega sistema že v novem veku (Fornasin 1998; Beguš 2015, 167-73), v zadnjih desetletjih 19. stoletja pa so se močno razširile tudi med kmečko prebivalstvo nižinske Furlanije. Do prve svetovne vojne so bila ta gibanja večinoma sezonska ali kratkodobna in niso imela negativnih demografskih posledic. Zahvaljujoč »izseljenski ekonomiji«, ki je prispevala vse večje deleže dohodka, je prebivalstvo naraščalo. Po vojni pa se je zaradi nove politične geografije in migracijskih politik, ki so sezonski delovni migraciji otežile dostop do tradicionalnih ciljev na ozemlju bivše avstro-ogrske monarhije, slika spremenila. Migracijska gibanja so se obrnila proti drugim državam in v notranjost Italije ter začela prehajati od začasnih oblik k stalnemu naseljevanju v mestih in nižinski gospodarskih središčih. S tem se je začela depopulacija hribovitih območij (Spopolamento 1938).

V Reziji, kjer je bil pojav izrazitejši, je število rezidenčnega prebivalstva do srede tridesetih let padlo za $45 \%$. V Nadiških dolinah je bilo odseljevanje manj številno, prebivalstvo je upadlo za $13 \%$. Kriza pa se je poglobila od petdesetih let dalje (tabela 2 in graf 1). V obdobju 1951-1981 je število rezijanskega in nadiškega prebivalstva upadlo za več kot polovico. Posebno kritična so bila šestdeseta leta, ko se je v Reziji prebivalstvo zmanjšalo za 36 \%, v Nadiških dolinah pa za 32 \%. Tolikšnemu demografskemu nazadovanju je v prvi fazi botrovalo množično odhajanje v iskanju zaslužka in sodobnega življenjskega standarda, v drugi pa, kot posledica izseljevanja, zmanjšana reproduktivna vitalnost in vse večja ostarelost prebivalstva (Stranj 1982, 133; Clavora in Ruttar 1990, 58-70; Kalc in Kodrič 1992, 206).

Tabela I. Gibanje števila prebivalstva v občinah Nadiških dolin v letih I92I-1990

\begin{tabular}{ccccccccc}
\hline Leto & 1921 & 1931 & 1936 & 1951 & 1961 & 1971 & 1981 & 1990 \\
\hline Prebivalcev & 17.640 & 16.358 & 15.397 & 16.195 & 14.293 & 9.649 & 8.051 & 7.247 \\
\hline Indeks rasti & 100 & 93 & 87 & 92 & 81 & 55 & 46 & 41
\end{tabular}

Vir: Clavora in Ruttar 1990, 59.

Izseljevanje je izviralo iz težkega stanja povojne italijanske ekonomije, ki je bilo v marginalnih hribovitih območjih posebno poudarjeno. Depopulacija je zajela hribovita območja celega alpskega loka, vendar je bil upad prebivalstva $\mathrm{v}$ furlanskem hribovju manj poudarjen kot v Beneški Sloveniji, saj je znašal 38 \%. V Beneški Sloveniji in Reziji so na obseg depopulacije vplivali tudi politični vzroki, povezani s slovenskim etničnim zna- 
čajem območja, mejo z Jugoslavijo in ideološkim konfliktom med vzhodom ter zahodom. S hladno vojno je bilo slovensko naselitveno območje ob meji »komunističnega slovanskega sveta« ujeto v vojaško cono. Meja je bila posejana $z$ vojaškimi objekti zahodnega pakta in vojaške služnosti so onemogočale gospodarsko izkoriščanje obsežnega dela agrarnih površin. Še bolj je h gospodarski depresiji prispevala italijanska politika utrjevanja vzhodne meje, katere cilj je bil razredčiti prebivalstvo in vtisniti območju italijanski značaj. Te cilje so oblasti zasledovale na več načinov. Pri prostorskem načrtovanju so Beneško Slovenijo, ki nima izrazito gorskih značilnosti in bi se lahko v celoti agrarno izkoriščala, uvrstile med gozdno-pašniška območja. S tem so omejile možnosti modernizacije in razvoja kmetijstva (Kalc in Kodrič 1992; 2007).

Protijugoslovanske politične sile in sami državni organi so na razne načine netili protislovensko gonjo in vzdrževali napeto politično ozračje. Vsak izraz slovenske identitete je bil nezaželen in ožigosan $\mathrm{z}$ nelojalnostjo do Italije, prebivalstvo je bilo deležno poniževanj in obtožb »slavokomunizma«, simpatizerji opozicijskih strank in sindikatov, pripadniki in podporniki narodnoosvobodilnih gibanj med vojno, narodni in kulturni aktivisti so doživljali diskriminacije, politično preganjanje, ustrahovanje in aretacije. Za strategijo napetosti so poleg uradne politike in državnih organov stale oborožene tajne organizacije $\mathrm{v}$ službi zahodnega vojaškega zavezništva, ki so bile na terenu zadolžene za organizacijo obrambe pred morebitno invazijo sil Varšavskega pakta. Člani teh organizacij, ki so bile izraz italijanskih vojaškoobveščevalnih služb, med njimi tudi domačini, so ves povojni čas izvajali nacionalistični pritisk na slovensko prebivalstvo (Zuanella 1998; Kalc 2002, 145-51). Izseljevanje je pomenilo tudi beg od morečega ozračja, ki je še v osemdesetih letih v Benečiji preprečevalo bolj sproščeno življenje.

Ker je bilo po vojni italijansko gospodarstvo $v$ težavah in je v državi vladala velika brezposelnost, se je izseljevanje iz Beneške Slovenije in Rezije obrnilo predvsem v tujino. K temu ga je usmerjala sama italijanska država, ki je »izvažanje« delovne sile vključila med programske smernice ekonomske politike in izseljencem tlakovala pot $\mathrm{z}$ meddržavnimi sporazumi za izmenjavo delovne sile. Prvo tako pogodbo je Italija sklenila leta $1946 \mathrm{z}$ Belgijo, ki ji je primanjkovalo rok za ponoven zagon svoje temeljne panoge, premogovništva. Leta 1947 so sledili sporazumi za sprejemanje italijanskih delavcev s Francijo, nato s Švico, z Nemčijo, Nizozemsko, Luksemburgom, Veliko Britanijo in s Švedsko (Komac 1991, 645-46). V belgijskih rudarskih središčih so nastale številne beneškoslovenske naselbine in ravno tako $\mathrm{v}$ drugih evropskih državah, kjer so se izseljenci zaposlovali predvsem v 
gradbeništvu in industriji. Dekleta so kot že med svetovnima vojnama stopala na trg gostinskega osebja in predvsem služenja pri družinah v italijanskih in tujih mestih (Mlekuž 2004). Med cilji te ženske delovne migracije je bila še v petdesetih letih tudi Velika Britanija (Kalc 200o). Del izseljencev se je v okviru mednarodnih shem usmeril tudi v prekooceanske dežele, in sicer v Argentino, Venezuelo, Brazilijo, Urugvaj, Kanado, Avstralijo in nekatere afriške države (Fotoalbum 1986; Kalc in Kodrič 1992, 207). Tudi tu še danes obstajajo številne beneškoslovenske skupnosti. Mnogi so se, zlasti v prvih povojnih letih, odpravljali v tujino na svojo roko in pogosto ilegalno. Delali so v težkih pogojih in brez zaščite pred izkoriščanjem. Nekateri so $\mathrm{v}$ prvih povojnih letih namesto $\mathrm{v}$ tujini iskali zaposlitve $\mathrm{v}$ Sloveniji. Zaradi ilegalnega odhoda in tudi iz političnoideoloških razlogov so jih po povratku v Italijo čakali sodni pregoni. Zaradi zakonskih zapletov in težav pri transferju prihrankov je bilo problematično tudi legalno izseljevanje $\mathrm{v}$ Slovenijo (Komac 1991, 647).

$\mathrm{Z}$ napredkom industrializacije in gospodarskim vzponom italijanskega gospodarstva se je izseljevanje obrnilo tudi proti notranjemu delovnemu trgu v severni Italiji, ki je pritegnil tudi povratnike iz tujine. Prelomnica v tej usmeritvi in $v$ procesu vračanja je bila popotresna obnova $v$ drugi polovici sedemdesetih in $v$ osemdesetih letih. Sama obnova, ki je bila $v$ primerjavi z drugimi potresnimi območji $v$ Italiji zelo uspešna, je ustvarila številne možnosti zaposlovanja in pognala $v$ tek tudi ostalo deželno ekonomijo. Zahvaljujoč Sloveniji, ki je ob potresu in po njem priskočila na pomoč sosednji Furlaniji in območjem v Benečiji, prizadetim s potresom, so nastala gradbena in druga podjetja. $V$ tem obdobju pa je $v$ severovzhodnih italijanskih deželah prišlo do pospešene industrializacije in splošnega gospodarskega razvoja po značilnem modelu malih in srednjih obratov, ki je omogočil občutno rast življenjskega standarda. Pospešena urbanizacija nižinske Furlanije je sovpadala $\mathrm{z}$ dodatno depopulacijo hribovitih območij. Kljub obnovi mnogih vasi in prisotnosti slovenskih oziroma mešanih slovensko-italijanskih podjetij $\mathrm{v}$ samih beneškoslovenskih dolinah (ta so v devetdesetih letih večinoma propadla) se je prebivalstvo še dalje selilo v nižinska urbana središča. Tudi povratniki iz tujine, ki so si popravili in preuredili svoje domove $\mathrm{v}$ beneškoslovenskih vaseh, so se večinoma stalno naselili $\mathrm{v}$ furlanskih centrih. Tako območje nove naselitve je bil geografski trikotnik lesarske industrije, specializiran $\mathrm{v}$ proizvodnji stolic. Beneškoslovensko prebivalstvo pa se je naselilo tudi drugod po Furlaniji in deloma drugih severnoitalijanskih deželah. $\mathrm{V}$ devetdesetih letih 20. stoletja je na omenjenem 
industrijskem območju v Furlaniji živelo 10.000 oseb, izhajajočih iz Rezije, Nadiških in Terskih dolin. Že prej pa je večina rezijanskega in beneškoslovenskega prebivalstva živela zunaj svojega zgodovinskega naselitvenega območja, v Italiji in drugod po svetu. (Komac 1991, 646-47).

\section{Migracije in "manjšinska ekonomija»}

Prostor, ki ga poznamo kot slovensko zamejstvo v Italiji, je glede na svoje naravne značilnosti, družbenoekonomske razmere in perspektive ter vplive zgodovinskih in sodobnih političnih dogajanj tudi z vidika migracijskih procesov ostajal raznolik. Beneška Slovenija in Rezija sta po vojni ohranjali tradicionalen izseljenski značaj. Izseljevanje je zaradi spremenjene tipologije doseglo svojo najakutnejšo stopnjo. Prišlo je do izpraznjevanja zgodovinskega etničnega naselitvenega območja in razširitve geografskega pojmovanja beneškoslovenske skupnosti oziroma izvora prebivalstva na območja nove naselitve. $Z$ vidika slovenske narodne manjšine preučevalci izpostavljajo dejstvo, da so načrti za odstranjevanje elementov »slovanstva « z vzhodne meje nacionalnega ozemlja, ki jih je Italija zasledovala od samega začetka v šestdesetih letih 19. stoletja, dosegli najvidnejše uspehe po 2. svetovni vojni, torej v času demokracije (Kalc in Kodrič 1992).

Drugače je bilo na Goriškem in Tržaškem. Po selitvah slovenskega (in drugega) prebivalstva, povezanih neposredno in posredno $\mathrm{z}$ »zgodovino « meje, so tako Gorica in druga gospodarska središča goriške pokrajine kot Trst ohranjali svojo atraktivno oziroma stabilizacijsko vlogo. Med tukajšnjimi Slovenci je bilo izseljevanje od šestdesetih let veliko manj poudarjeno. Temu je ključno botrovala vsestranska organiziranost narodne manjšine, ki je s postopno relaksacijo političnih odnosov med Italijo in Jugoslavijo igrala obojestransko povezovalno vlogo. Meja med Italijo in Jugoslavijo, ki je od sedemdesetih let dalje slovela kot »najbolj odprta meja v Evropi«, je na območju z naravnimi in infrastrukturnimi danostmi ter zgodovinsko tradicijo gospodarskih izmenjav postala velika gospodarska priložnost. Slovenska narodna manjšina je ob podpori socialistične Jugoslavije s svojimi gospodarskimi organizacijami igrala vlogo posrednika med kapitalističnim in socialističnim družbenogospodarskim redom. T. i. družbeno gospodarstvo, od podjetij do bank in zadružnogospodarskih ustanov, ki se je razvilo v manjšinskem kontekstu, je slovenski skupnosti omogočalo obstoj in razvoj, profesionalne kulturne in družbene organizacije, ki so se financirale iz virov iz Slovenije, ter zagotavljalo veliko število delovnih mest. Enako velja za javno upravo, zlasti na ravni občin, in predvsem 
za šolstvo (italijanske osnovne in srednje šole s slovenskim učnim jezikom), ki je bilo (in je še) področje najštevilnejšega zaposlovanja pripadnikov slovenske narodne manjšine. Vse to je slovensko prebivalstvo na Goriškem in Tržaškem sistemsko navezovalo na manjšinski prostor in mu ponujalo priložnosti za stabilno gospodarsko in družbeno življenje (Pahor 1998). Ne glede na svetovnonazorska razhajanja ter politična nasprotja je ustvarjalo tudi pogoje za relativno družbeno in kulturno kohezijo okrog manjšinskih interesov. Izseljevanje iz profesionalnih, delovnih in drugih razlogov seveda ni bilo odsotno. Usmerjeno je bilo v italijanski prostor, v tujino in tudi v Slovenijo, kjer je bilo pogosto povezano s predhodnim študijem. Ni pa predstavljalo relevantnega družbenega problema (Stranj 1992).

\section{Organiziranost zamejskega izseljenstva in identitetni vidiki}

Izseljenci iz Beneške Slovenije in Rezije so se v krajih priseljevanja med seboj povezovali, zlasti kjer je bila naselitev bolj strnjena in jih niso ločevale prevelike razdalje. Organizacijsko pa so se prepoznavali v furlanskem izseljenstvu in se pridruževali furlanskim izseljenskim društvom. Ta so imela dolgo tradicijo in izseljencem nudila, poleg priložnosti za druženje in ohranjanje kulturnih vrednot, razne usluge in oporo pri soočanju $\mathrm{z}$ delovnimi vprašanji in življenjem na tujem.

V drugi polovici šestdesetih let se je med izseljenci v Švici porodila želja po samostojni organizaciji. Izvirala je iz skrbi zaradi naraščanja izseljenskega pojava in zavedanja negativnih posledic, ki jih je imel tolikšen odliv prebivalstva na prihodnost in sam obstoj Benečije. V tujini izseljenci niso bili neposredno podvrženi italijanskemu nacionalističnemu pritisku in so začutili priložnost, da se aktivno zavzamejo tako za svoje delavske pravice kot tudi za jezikovne in kulturne tradicije. Ta socialni in narodni emancipacijski čut je leta 1968 v mestecu Orbe, v švicarskem kantonu Vaud, privedel do ustanovitve Društva beneških emigrantov (Komac 1992). Namen društva je bil povezati izseljence iz Beneške Slovenije v samostojni organizaciji, da bi lahko ohranjali in izražali svojo narodno in kulturno identiteto. Izseljenci naj bi na ta način kot organiziran subjekt delovali proti izseljevanju in družbenoekonomskemu propadanju ter za uveljavljanje narodnih pravic v Benečiji. Društvo se je rodilo s pomočjo manjšinskih organizacij iz Trsta in Gorice v okviru prizadevanj za ustvarjanje enotnega manjšinskega prostora in vključevanje Slovencev iz videmske pokrajine, ki niso uživali statusa manjšine, $v$ procese razvoja slovenske manjšine $\mathrm{v}$ Italiji in uveljavljanja narodnih pravic. Društvo beneških izseljencev se je v 
70. letih preselilo iz Švice v Čedad. Medtem so po beneškoslovenskih naselbinah v Evropi, v Severni in Južni Ameriki ter Avstraliji nastajala številna nova društva. Društvo v Čedadu je vsa društva povezalo in se spremenilo v krovno Zvezo slovenskih izseljencev iz Beneške Slovenije. Leta 1980 je dežela Furlanija-Julijska krajina Zvezo uvrstila med javno priznane organizacije za zastopanje in vzdrževanje vezi z izseljenci iz te dežele. Od takrat se organizacija imenuje Zveza slovenskih izseljencev iz Furlanije Julijske krajine in nastopa kot organizacija slovenskih izseljencev celotnega manjšinskega prostora v Italiji (Clavora, Ruttar in Mattelig 1988).

Zveza je sicer še naprej ostala prvenstveno organizacija izseljencev iz Videmske pokrajine, ki so se $\mathrm{v}$ priseljenskih deželah prepoznavali v specifikah beneškoslovenskega geografskega in kulturnega prostora. Slovenski izseljenci iz ostalega zamejskega območja so namreč izhajali iz drugačnih zgodovinskih okoliščin in izkušenj. Pripadali so drugačnemu socialnemu in kulturnemu identitetnemu okolju. To se odraža tudi v njihovem življenju, udejstvovanju in identitetnih značilnostih $\mathrm{v} »$ novih domovinah".

Tržaških Slovencev, ki so se izselili $\mathrm{z}$ avstralskim valom $\mathrm{v}$ petdesetih letih, ni mogoče obravnavati v smislu samostojne ali narodno opredeljene skupnosti. V Avstraliji so zaživeli predvsem kot tržaški priseljenci, ohranjali so vezi $v$ tem etnično in jezikovno mešanem ter prepletenem družbenem kontekstu, čeprav so gojili stike tudi s slovenskimi, točneje primorskimi priseljenci in njihovimi društvi. S temi so imeli zaradi predvojne in tudi povojne pripadnosti skupnemu ozemlju (Julijski krajini) kulturne in vsakodnevne življenjske afinitete. Niso pa se povezali in organizirali na podlagi »slovenskih korenin«. Mnogi so bili vključeni in se aktivno udejstvovali v okviru tržaških skupnosti in njihovega društvenega življenja, v okviru katerega pa so ostali navzven narodno nerazpoznavni. Ta položaj je bil sad okoliščin, potreb, izbir in v veliki meri tudi družbenih, kulturnih ter političnih procesov znotraj tržaških priseljenskih skupnosti v Avstraliji in njihovih odnosov z izvornim mestom (Kalc 2001).

V tržaških naselbinah v Avstraliji so se v malem reproducirale tržaške situacije. Zaživele so etnično in jezikovno mešane skupnosti, v katerih pa je kot sporazumevalni jezik prevladalo tržaško italijansko narečje, ki je bilo tudi materin jezik večinskega dela priseljencev. Mešan je bil tudi čut kulturne oziroma etnične pripadnosti, ki se je v času spreminjal in ki ga ni mogoče opredeljevati na podlagi shematične narodne delitve. Za mnoge tržaške izseljence je bila prej kot narodna značilna lokalna, razredna, delavska in idejna - indipendentistična identifikacija, čeprav ni manjkalo ne itali- 
janskega ne slovenskega čuta narodne pripadnosti. Ta dva čuta sta sobivala, podobno kot na Tržaškem, nadaljevala pa se je tudi asimilacija, povezana včasih z mešanimi porokami, včasih s prilagajanjem dominantnemu italijanskemu »tržaštvu« (Kalc 2007).

Formalna organiziranost med tržaškimi priseljenci v Avstralijo ima svojevrstno zgodovino, tesno povezano s političnimi dogajanji v izvornem kraju pred in $\mathrm{v}$ desetletjih po preselitvi. Tržačani se v prvih letih niso organizirali v samostojna društva, obiskovali so prireditve, ki so jih organizirale druge skupnosti, večinoma italijanske, Slovenci pa so zahajali tudi na slovenske. Začetki organiziranosti tržaških priseljencev segajo v leto 1961, ko je v Sydneyu nastalo društvo Associazione Trieste. Ustanovili so ga bivši uslužbenci policije Svobodnega tržaškega ozemlja. Organizacija je temeljila na »tržaški pripadnosti« in predstavljala interese "večnarodnega mesta« Trsta, ne glede na svetovne nazore. Zagovarjala je večnarodni značaj tržaškega priseljenstva, složnost vseh njegovih narodnih komponent in izogibanje identifikaciji z italijanstvom ter povezovanju $\mathrm{z}$ Italijo. Včlanjevala je izključno osebe, rojene na ozemlju cone A STO, odklanjala istrske in dalmatinske »ezule« ter odnose z Italijo. Društvo je poleg družbene, kulturne in publicistične dejavnosti članom pomagalo s socialno blagajno in $\mathrm{z}$ nakupovalno zadrugo. Pozivalo je $\mathrm{k}$ apolitičnosti, nadstrankarstvu in nasprotovanju nacionalizmom. Poudarjalo je "tržaškost« in drugotni pomen italijanske, slovenske ali hrvaške narodnosti članov.

Ta linija je kmalu dobila notranje in zunanje nasprotnike, med temi italijansko avstralsko časopisje, ki je društvu očitalo odpadništvo in antiitalijanstvo. Društvo ni imelo stikov ne z italijanskimi konzularnimi predstavniki ne $\mathrm{z}$ oblastmi v Trstu, medtem ko so druga društva, ki so združevala tržaške in istrske priseljence, uživala podporo Italije in njenih regionalnih izseljenskih organizacij. Med temi je bilo združenje Giuliani nel mondo, ki je bilo zadolženo za izseljence iz Julijske krajine. V tej organizaciji so prevladovali begunci iz Istre in Dalmacije, vzdrževala je oster protikomunistični in protijugoslovanski naboj. Odklonilen je bil tudi njen odnos do slovenske manjšine v Italiji. Na začetku sedemdesetih let so vodilni tržaški demokrščanski politiki v imenu "sprave" med izseljenci bivšega STO in Italijo privabili Associazione Trieste pod okrilje organizacije Giuliani nel mondo. Sledili so spori in delitev tržaške priseljenske skupnosti na zastopnike samostojne tržaške linije in tiste, ki so zagovarjali združevanje $\mathrm{z}$ Istrani. Leta 1983 so se končno vsa društva, ki so nastala iz delitev, včlanila v federacijo združenja Giuliani nel Mondo in prejemala finančna 
sredstva iz Italije. V federaciji pa so prevladale organizacije istrskih »esulov«, ki so v njej ustvarile protijugoslovansko revanšistično in nacionalistično klimo.

Interesi Tržačanov so se s sprejemanjem logike povezovanja vseh priseljencev iz Julijske krajine podredili interesom številčnejše in glasnejše skupine, katere glasnik je bilo v Trstu in v Avstraliji združenje Giuliani nel Mondo. Glavni cilj tega združenja, ki je imelo denarnico z javnimi sredstvi za izseljence iz Julijske krajine, je bil zastopati interese »ezulov«. Objektivno gledano, tržaška ideja ni imela pravih pogojev, da bi se dolgoročneje ohranila, ker za sabo ni imela »domovine«. Ohranjanje »idealne« tržaške skupnosti, sklicujoč se na ideološke temelje STO, ni imelo perspektive. STO ni bilo več in Trst je postal »najbolj italijansko mesto v Italiji« (Cresciani 2011, 121-63).

Položaj in vloga Slovencev v tej zapleteni zgodbi sta neraziskano poglavje. Vprašanje je $\mathrm{v}$ akademskih in poljudnih delih italijanskih avtorjev o tržaškem izseljenstvu v Avstraliji povsem spregledano. Pogostokrat je zamolčana sama prisotnost Slovencev med tržaškimi priseljenci (prim. Donato in Nodari 1995; Fait 1999; Nelli 1999; Nodari 1991; Facchinetti 2008). Razloge za anonimizacijo slovenske komponente v tržaškem izseljenstvu v Avstraliji je mogoče iskati v dogajanju okrog društvene organiziranosti in $\mathrm{v}$ pisanju zgodovine na podlagi metodološkega nacionalizma ter $\mathrm{v}$ funkciji nacionalnih vrednot. Tržaško izseljevanje v Avstralijo se skupaj z »emigracijo iz Julijske krajine« (emigrazione giuliana) prikazuje preprosto kot italijansko. Kompleksna slika tržaške prisotnosti v Avstraliji, s svojimi edinstvenimi etničnimi in kulturnimi vsebinami ter intimnimi čutenji, je bila prekrita s politično funkcionalnejšo in všečnejšo nacionalno prevleko. Zaradi prevlade nacionalnega ključa in usklajevanja raziskav z državnimi mejami je tržaški primer izpadel tudi iz vodilnih slovenskih del o izseljevanju v Avstralijo (prim. Čebulj Sajko 1992; Koderman 2015). Razumevanje problematike (in $\mathrm{z}$ migracijami povezanih identitetnih vprašanj nasploh) predpostavlja, kot poudarjajo nekateri avtorji (Kalc 2007; Panjek 2011; Purini 2010; Cresciani 2011), nadnacionalni pristop in poglabljanje v socialno, kulturno ter intimno sfero skupin in posameznikov.

\section{Zaključna misel}

Kot je razvidno iz nakazane slike, je bil slovenski zamejski prostor $\mathrm{v}$ Italiji po drugi svetovni vojni migracijsko izredno razgiban. Čeprav so na preseljevanja $\mathrm{v}$ vseh primerih vplivale tudi ekonomske in socialne motiva- 
cije, so bila glavna gibala transferjev oziroma situacij, iz katerih so se le-ti rojevali, izrazito politična. $V$ novi povojni geopolitični delitvi stičnega italijansko-jugoslovanskega (oziroma slovenskega in hrvaškega) ozemlja so se nadaljevali procesi prerazporejanja prebivalstva, ki so od konca prve svetovne vojne sledili težnji držav po narodni homogenizaciji obmejnih območij, po drugi vojni pa tudi potrebi po utrjevanju ideoloških okopov. Ideja multietnične državne tvorbe Svobodnega tržaškega ozemlja, ki naj bi blažila italijansko-jugoslovanski mejni spor in blokovske napetosti, je morala popustiti ureditvi teritorialnega vprašanja po nacionalni logiki in s tem dokončno razprla scenarij prerazporejanj ter zamenjav prebivalstva. Hkrati pa se je, nasprotno situaciji po prvi vojni, vendarle uveljavilo tudi načelo priznavanja avtohtonih narodnih manjšin. To načelo, utemeljeno in $\mathrm{v}$ desetletjih nadgrajeno $\mathrm{z}$ mednarodnimi ter dvostranskimi sporazumi, je slovenski manjšinski prostor $v$ Italiji delilo na dva pravno ločena dela, dokler ni zapletena in naporna pot zaščitne zakonodaje tudi beneškim in drugim Slovencem v Videmski pokrajini prinesla priznanja statusa narodne manjšine. Prikazana migracijska gibanja v tem prostoru, njihovi vzgibi in posledice so bili del dogajanj s številnimi akterji, ki so se odvijala hkrati na lokalnih, nacionalnih in mednarodnih političnih šahovnicah. Bila so tudi posledica različnih vizij meje in državnih relacij na meji ter odnosa do narodnih manjšin.

Prispevek je nastal na podlagi raziskav, sofinanciranih iz programa "Narodna in kulturna identiteta slovenskega izseljenstva $v$ kontekstu raziskovanja migracij" (ARRS, $\mathrm{P}_{5}$-0070 ) ter projektov "Socialna, gospodarska in kulturna zgodovina slovenskega izseljenstva (1945-1991)« (ARRS, J5-8246) in »Nadzor nad migracijami na Slovenskem od AvstroOgrske do samostojne Slovenije« (ARRS, J6-8250).

\section{Viri in literatura}

\section{Objavljeni viri}

\section{Primorski dnevnik}

Stranj, P. 1991. »Ladijska sirena je piskala vsem nam.« Primorski dnevnik, 21. april 1991. 


\section{Literatura}

Bajc, G. 2010. »Vloga in delovanje politične emigracije iz osrednje Slovenije v povojnem Trstu." V Migracije in slovenski prostor od antike do danes, Zbirka ZČ 39, ur. P. Štih in B. Balkovec, 376-94. Ljubljana: Zveza zgodovinskih društev Slovenije.

Bearzatto, F. 2012. Soppravvissuto a Buchenwald e al Vajont. Portogruaro: Nuova dimensione.

Beguš, I. 2015. Avtonomija in ekonomija Nadiških dolin v Beneški republiki. Koper: Univerzitetna založba Annales.

Clavora, F., in R. Ruttar 1990. La comunità senza nome: la Slavia alle soglie del 20oo. Premariacco: Zveza slovenskih izseljencev Furlanije Julijske krajine.

Clavora, F., R. Mattelig in R. Ruttar 1988. L'Unione Emigranti Sloveni al servizio della propria comunità. Čedad: Unione Emigranti Sloveni del FriuliVenezia Giulia.

Cresciani, G. 1999. "Storia e caratteristiche dell'emigrazione giuliana, istriana, fiumana e dalmata in Australia." V Giuliano dalmati in Australia: Contributi e testimonianze per una storia, ur. G. Cresciani, 61-84. Trst: Associazione Giuliani nel mondo.

Cresciani, G. 2011. Trieste Goes to Australia. Lindfield: Padana Press.

Čebulj Sajko, B. 1992. Med srečo in svobodo: avstralski Slovenci o sebi. Ljubljana: samozaložba.

Donato, C., in P. Nodari 1995. »L'emigrazione giuliana nel mondo: note introduttive.« Quaderni C. S. E. P. E. Vanoni di Trieste 3-4.

Facchinetti, V. 2008. Storie fuori dalla storia: ricordi ed emozioni di emigrati giuliano-dalmati in Australia. Trst: LINT.

Fait, F. 1999. L'emigrazione giuliana in Australia (1954-1961). Videm: ERMI.

Fornasin, A. 1998. Ambulanti, artigiani e mercanti. L'emigrazione dalla Carnia in età moderna. Videm: Cierre Edizioni.

Fotoalbum. 1986. Fotoalbum izseljencev iz Benečije: šstudijami o posameznih migracijskih obdobjih/Fotoalbum degli emigranti della Benecia: con saggi sui periodi del fenomeno migratorio. Trst: ZTT.

Gombač, J. 2005. Esuli ali optanti? Zgodovinski primer v luči sodobne teorije. Ljubljana: Založba ZRC.

Kalc, A. 200o. »Prispevki za zgodovino izseljevanja iz Beneške Slovenije: primer občine Sovodnje/Savogna.« Dve domovini 11/12: 175-200. 
Kalc, A. 2001. »Iz Trsta v Avstralijo.« V M. Kokalj Kočevar, D. Kramberger, J. N. Zwitter, M. Cregeen in D. Koprivec, Izseljenec: življenjske zgodbe Slovencev po svetu, 113-16. Ljubljana: Muzej novejše zgodovine.

Kalc, A. 2002. Poti in usode: selitvene izkušnje Slovencev z zahodne meje. Koper; Trst: ZDPJ, ZRS, NŠK.

Kalc, A. 2004. »Pisma in magnetofonski trakovi kot komunikacijska sredstva in viri za preučevanje izseljenstva: primer tržaške družine v Avstraliji.« Dve domovini 20: 153-74.

Kalc, A. 2007. "Semo stadi sai contenti de sentir le vostre vosi‘. Emigrazione e comunicazione: il caso di una famiglia triestina emigrata in Australia.« Qualestoria 35 (1): 13-35.

Kalc, A. 2019. »The Other Side of the 〈Istrian Exodus»: Immigration and Social Restoration in Slovenian Coastal Towns in the 1950s." Dve domovini 49: 145-62.

Kalc, A., in Kodrič M. 1992. »Izseljevanje iz Beneške Slovenije v kontekstu furlanske emigracije.« Zgodovinski časopis 46 (2): 197-209.

Kalc, A., in M. Pahor 1993. Relazione sulla ricerca sperimentale del progetto di studio »Gli sloveni di Trieste e l'esperienza australiana«. Trst: Narodna in študijska knjižnica - Odsek za zgodovino in etnografijo (tipkopis).

Koderman, M. 2015. Nazaj v domači kraj: prostorske in turistične razsežnosti obiskovanja Slovenije strani slovenskih izseljencev in njihovih potomcev iz Avstralije. Koper: Univerzitetna založba Annales.

Komac, M. 1991. »Migracijski procesi v Furlaniji-Julijski krajini s posebnim ozirom na Beneško Slovenijo.« Zgodovinski časopis 45 (4): 639-49.

Komac, M. 1992. »Od pasivne k aktivni emigraciji: zveza slovenskih izseljencev iz Furlanije-Julijske krajine: njen nastanek ter delovanje do potresa leta 1976. "Razprave in gradivo 26/27: 51-71.

Lavrenčič, L. 2012. »Demografska slika italijanske manjšine v Kopru po poteku roka za izselitev leta 1956." Acta Histriae 20 (3): 505-32.

Mlekuž, J. 2004. »Zbrani vidiki zaposlovanja beneških deklet v gospodinjstvih italijanskih mest: tiha, grenko-sladka, nikoli povsem izrečena in slišana zgodba." Dve domovini 19: 141-164.

Nelli, A. 1988. »Triestine Clubs in Australia."V The Passeggiata of Exile: The Italian Story in Australia, ur. R. Pascoe in J. Ronayne. Melbourne: Victoria University of Technology.

Nelli, A. 1999. „L'esperienza migratoria triestina: l'identità culturale e i suoi cambiamenti.« V Giuliano dalmati in Australia.: contributi e testimoni- 
anze per una storia, ur. G. Cresciani, 85-96. Trst: Associazione Giuliani nel mondo.

Nodari, P. 1986. I rientri degli emigrati dall'Australia nel periodo 1972-1977, con particolare riguardo al Comune di Trieste. Quaderni dell'Istituto di Geografia dell'Università di Trieste 4.

Nodari, P. 1991. La comunità giuliana di alcune città australiane: Sydney, Adelaide, Melbourne. Trst: Università di studi di Trieste.

Pahor, M. 1998. Lastno gospodarstvo jamstvo za obstoj. Pregled gospodarskih dejavnosti Slovencev na področju sedanje Furlanije-Julijske krajine 1848-1998. Trst: SDGZ.

Panjek, A. 2011. Tržaška obnova: ekonomske in migracijske politike na Svobodnem tržaškem ozemlju. Koper: Univerzitetna založba Annales.

Purini, P. 2010. Metamorfosi etniche: i cambiamenti di popolazione a Trieste, Gorizia, Fiume e in Istria 1914-1975. Videm: KappaVu.

Spopolamento. 1938. Lo spopolamento montano in Italia. Le Alpi Venete. Rim: Comitato per la geografia del Consiglio nazionale delle ricerche, Istituto nazionale di economia agraria.

Stranj, P. 1982. Poskus ocenitve števila tržaških Slovencev, ki so se izselili v Avstralijo. Trst: Slovenski raziskovalni inštitut (hrani OZE NŠK Trst).

Stranj, P. 1992. La comunità sommersa: gli Sloveni in Italia dalla A alla Ž. Trst: Editoriale stampa triestina.

Tonel, C. 1999. Arriva la madre, i figli partono: l'emigrazione in Australia di 20.ooo triestini. Trst: Associazione Culturale Regionale Enrico Berlinguer.

Troha, N. 1999. Komu Trst: Slovenci in Italijani med dvema državama. Ljubljana: Modrijan.

Troha, N. 200o. »Preselitve v Julijski krajini po drugi svetovni vojni.« Prispevki za novejšo zgodovino 40 (1): 255-68.

Troha, N. 2010. »Odseljevanje in prebegi Slovencev z območja, ki je bilo z mirovno pogodbo z Italijo leta 1947 priključeno ljudski republiki Sloveniji.« V Migracije in slovenski prostor od antike do danes, Zbirka ZČ 39, ur. P. Štih in B. Balkovec, 432-46. Ljubljana: Zveza zgodovinskih društev Slovenije.

Vidmar, J. 2015. »Nadzor in represija na meji med Jugoslavijo (FLRJ) in Italijo v letih 1947-1954."Kronika 63 (1): 119-36.

Volk, S. 1998. »Slovenska politična emigracija v Trstu do leta 1954.«Zgodovinski časopis 52 (1): 87-109. 
Volk, S. 1999. Ezulski skrbniki: vloga in pomen begunskih organizacij ter urejanje vprašanja istrskih beguncev v Italiji v luči begunskega časopisja 19451963. Koper: ZDJP, ZRS.

Volk, S. 200o. "Zakonodaja Zavezniške vojaške uprave o istrskih beguncih (1945-1947-1954)«. Prispevki za novejšo zgodovino 6o/1: 269-283.

Volk, S. 2003. Istra v Trstu: naselitev istrskih in dalmatinskih ezulov in nacionalna bonifikacija na Tržaškem. Koper: UP ZRS, ZDJP.

Zuanella, N. 1998. Mračna leta Benečije: dejavnost tajnih organizacij v vzhodni Furlaniji. Ljubljana: Cankarjeva založba.

\section{Summary}

Migration movements in the Slovenian ethnic area in northeastern Italy in the decades after WWII

The article deals with migratory movements in the decades following the Second World War in the settlement area of the Slovene national minority in Italy. These movements were affected by the border issue between Italy and Yugoslavia and by the national, political, and ideological conflicts of the post-war period. Immigration and emigration phenomena, which in several phases marked the border area under scrutiny influencing its social, ethnic, and political characters are presented. These migration phenomena concern the Italian and Slovene political refugees who fled from Yugoslavia, the optants who, based on the 1947 peace treaty and the 1954 London agreement, chose the Italian citizenship and left Istria and other former Italian territories that passed under Yugoslavia. The migration policies of the Italian and Yugoslav authorities and the Allied Military Administration, as well as the political implications of the mass settlement of refugees and optants from Istria and Dalmatia in Trieste, are discussed. The role and influence of the Slovene anti-communist political emigration in the Slovene national community in the political and cultural field are presented.

As pertains the emigration processes, the emphasis is on two mass phenomena. The first is the departure of about 15,000 to 20,000 people from the Trieste area to Australia in the years following the dissolution of the Free Territory of Trieste (1954). This emigration emerged as a reaction to the economic and housing crisis and was fuelled by the protracted political conflict and a sense of frustration and mistrust towards the Italian state 
among the leftist workers, the Slovenes, and those who supported the experiment of Trieste as an independent state.

The second phenomenon is the depopulation of Venetian Slovenia in the northern part of the Italian territory along the state border with socialist Yugoslavia and today's Republic of Slovenia. The phenomenon was originated, as in other hilly Italian areas, by unfavourable socio-economic conditions. At the same time, it was also encouraged by a deliberate economic policy aimed at diminishing the presence of the Slovene population and by an artificially created nationalist climate, which in the spirit of the Cold War and Italian patriotism, associated the Slovene population with the "Slav-communist" danger.

The article also draws attention to the differences in the organization and identification of Slovene emigrants from Venetian Slovenia and Trieste abroad. This was also significantly influenced by the political situation in their areas of origin. While emigrants from Venetian Slovenia created a network of ethnically-based communities and organizations, Slovene emigrants from Trieste in Australia formed a "Trieste origin" community with the Italian emigrants. Due to the state affiliation of Trieste with Italy, the numerical dominance of the Italian component and the Italian language of communication in immigrant communities, as well as the assimilation process and the political activities of pro-Italian groups, these communities and their associations have lost their ethnically and culturally mixed character and acquired an Italian national one. 